\title{
Üniversite Öğrencilerinin Film İzleme Tercihlerini Etkileyen Faktörler: Bingöl Üniversitesi Örneği
}

\section{Dr.Öğr.Üyesi Ali Ulvi Özbey ${ }^{{ }^{*}}$}

Gelis tarihi: 27.08 .2019

Kabul tarihi: 11.09.2019

\section{Atıf bilgisi:}

IBAD Sosyal Bilimler Dergisi

Sayı: Özel Sayı $\quad$ Sayfa: $217-231$

Yıl: 2019

This article was checked by iThenticate Similarity Index $18 \%$.

${ }^{1}$ Bingöl Üniversitesi, Türkiye,

ORCID ID 0000-0002-7880-8312

\section{$*$ Sorumlu yazar}

\section{$\ddot{o z z}$}

$\mathrm{Bu}$ araştırma, üniversite öğrencilerinin film tercihlerini etkileyen faktörleri araştırmaya yönelik betimleyici bir çalışmadır. Bingöl Üniversitesi sosyoloji bölümünde eğitim gören yaklaşık 100 üniversite öğrencisi için hazırlanan bir anket formu uygulanmıştır. $\mathrm{Bu}$ anket formu, öğrencilerin en çok hangi tür film izlediklerine, ne siklıkla sinemaya gittiklerine, film izlemedeki temel motivasyonunu ne olduğuna dair sorular içermektedir. Ankete verilen cevaplar betimleyici istatistiklerle ele alınmış, ve cinsiyet değişkenine göre farklılaşmalar sınanmıştır. Sonuçlar üniversite öğrencilerinin film izlemedeki temel değişkenleri ortaya konmasının yanında o yaş aralığıyla ile ilgili entelektüel anlamda birtakım soruların cevabına ulaşmada yol gösterici olmuştur. Ayrıca film tercihlerinde cinsiyete göre çeşitli farklılıklarla birlikte bazı benzerlikler de gözlenmiştir. Söz konusu bulgular 1şığında, üniversite öğrencilerinin sinema ve filmlerideki tür ve amaçları modern kültür açısından tartışılacaktır.

Anahtar Kelimeler: Film, tercih, cinsiyet, anket. 


\section{Factors Affecting University Students' Choice of Watching Movies: The Simple of Bingöl University}

\section{Dr.Öğr.Üyesi Ali Ulvi Özbey ${ }^{1^{*}}$}

First received: 27.08 .2019

Accepted: 11.09.2019

\section{Citation:}

IBAD Journal of Social Sciences

Issue: Special Issue Pages: 217-231

Year: 2019

This article was checked by iThenticate. Similarity Index $18 \%$.

${ }^{1}$ Bingöl Üniversitesi, Türkiye, aliulviozbey@hotmail.com ORCID ID 0000-0002-7880-8312

$*$ Corresponding Author

\section{ABSTRACT}

This study is a descriptive study to investigate the factors affecting the film preferences of university students. A questionnaire was prepared for approximately 100 university students studying sociology at Bingöl University. This survey form includes questions about what kind of movies they watch most, how often they go to the movies and what is their main motivation in watching movies. The answers given to the survey were handled with descriptive statistics and differences were tested according to gender variable. The results showed that the main variables of the university students in watching movies, as well as the intellectually related questions about the age range to reach the answers. In addition, some similarities were observed in the film preferences with respect to gender. In the light of these findings, the genres and aims of university students in cinema and films will be discussed in terms of modern culture.

Keywords: Film, preference, gender, survey. 


\section{GİRIŞ}

Sinema (cinéma) sözcüğü sinematografi (cinématographie) sözcügünden kısaltılmıştır. Lumière Kardeşler kendi buluşları olan aygita sinematograf (cinématographe) adını vermişlerdi. Yunanca "kinêma, -atos = devinim" ile "graphein = yazmak" sözcüklerinden türetilen sinematograf, "devinimi yazan, saptayan" anlamına, sinematografi de "devinimi yazma, saptama" anlamına gelmektedir. Sinema sözcüğü zamanla filmlerin gösterildiği yapı, yer; sinema çalışmalarının tümü, sinema işleyimi (endüstrisi) kavramlarını kapsayacak biçimde anlam genişlemelerine uğramışsa da bizi burada ilgilendiren ilk ve temel kavram "devinimi yazma, saptama"dır. Bu anlamda sinema, herhangi bir devinimi düzenli aralıklarla parçalara bölerek bunların resimlerini saptamayı, sonra gösterici yardımıyla bu resimleri karanlık bir salonda görüntülük üzerine yansıtarak devinimi yeniden oluşturmayı ifade etmektedir (Özön, 1984, s. 7).

Sinema genelde, uygulamalı (teknik bir icat olarak sinema bilimsel bir araçtır) alandan çevresel, resimsel, dramatik ve anlatısal alanlardan geçerek müziğe kadar bütün alanları kapsar. Her ne kadar sinemayı en iyi biçimiyle dramatik sanatlardan biri olarak biliyorsak da sinema güçlü bir biçimde resimseldir. $\mathrm{Bu}$ da filmlerin neden kütüphanelerde değil de çoğunlukla müzelerde toplandığını açıklamaktadır (Monaco, 2000, s. 33). Sinema tesadüfen değil, esasen kitlesel bir ortamdır. Ona hitap ettiği kadar kitlesel bir zihniyet yaratır. Sinema, seyirciyi, kendisini ve şimdikiyle olan etkileşimini teknolojik geçmişi olan ve yalnızca geçmişinin kopyalarını ortaya koyabilecekleri şeyleri kaydettiği sürece aldatabilir. Fenomenlerin kopyalanmasındaki teknolojik yeterlilik sinemanın başlangıç noktası iken görsel sanatlarda amacın ta kendisidir (Phillips, 2008, s. 6).

Türk düşünce ve yazın dünyasına sinema alanına yaptığı katkılarıyla bilinen önemli entelektüellerinden Nijat Özön, sinemanın taşımış olduğu farklı kimlikler üzerinden sinemaya farklı tanımlar getirmiştir. Ona göre sinema çok yönlü bir zihin dünyasına sahiptir. Görsel-işitsel imler sinemanın bir iletişim, bildirişim aracı olmasını sağlamaktadır; sinema eğitim-öğretim aracı olarak da kullanılabilir. Bilgileri aktarışındaki yoğunluk, kestirmelik ve kıvraklıktan dolayı okul ve okul dışında en etkili eğitim-öğretim sinemayla sağlanabilir. Sinemayı bir propaganda aracı olarak da kullanabiliriz. Üstelik görüntülerinin inandırıcılığı, kandırıcılığı ve etkililiği yüzünden propaganda araçlarının en güçlüsüdür. Sinemanın bir eğlence aracı olmak özelliği de vardır; insanların boş zamanlarını doldurmakta, onların hoşça vakit geçirmelerinde, oyalanmalarında kullanılabilir (Özön, 1984, s. 8).

\section{Sinema ve Gençlik Üzerine}

İlk ortaya çıktığında bir sanat olarak değerlendirilmeyen sinemaya ilk ciddi yaklaşımlar ise kuramcılar sayesinde olmuştır. Sinemayı ciddiyetle ele alıp psikolojik, sosyolojik ve estetik yönlerini analiz eden bu ilk film kuramcıları sinemanın bir sanat olduğunu kanıtlama iddiasındadırlar ve öncelikle sinemanın tiyatrodan ve de fotoğraftan ayrı bir sanat olduğunu göstermeye çalışırlar. O, gerçekliği gösterdiği ya da en azından gerçeklik yanılsaması yarattığı için diğer sanatlardan ayrı bir yerde olmalıdır. Sinemanın temel kavramlarını açıklarlar. "Neden film izleriz", "film izlemek insanın hangi ihtiyacına karşılık gelir" gibi soruların cevabını bulmaya çalışırlar (Özarslan, 2015, s. 15).

Birçok yazar ve araştırmacı tarafından medyanın medya mesajlarına savunmasız olan gençleri olumlu ya da olumsuz etkilediğine dair sayısız araştırma ve kitabı mevcuttur çünkü bu kişilere göre gençlerin zihinlerinin özellikle etkilenebilir olması onları medya endüstrileri tarafindan hedef kılmaktadır. Dolayısıyla gençlerin ne tür film izledikleri ve sonunda ne tür fikirlere sahip oldukları bütün ülke insanını etkilemektedir (Shary \& Seibel, Youth Culture in Global Cinema, 2007, s. 2).

Özellikle 1900'lerden itibaren batıda yaşayan işçi sınıfının yorgun geçen günün sonunda film izlemeyi bir rahatlama aracı olarak tercih etmesi belli bir döneme kadar devam etmiştir. Sonraki süreç sinemanın gerçek hüviyetine döndüğü asli unsurunu ve misyonunu kazandığı dönem olmuştur. André Bazin'in Sinema Nedir? isimli eserinde tanıtım bölümünde düşüncelerini ifade eden Hughy Gray'e göre, tüm dünyada sinema bir kaçış yolu olmaktan çıkarak bize hayatın gerçeklerini sunabilecek bir araç olma yolunda ilerlemiştir. Artık gördügümüz ekran, yaşamın bunalımlarından bir süre için uzaklaşmayı değil, bize o yaşama karşı daha hazırlıklı olma yöntemini öğreten bir konuma girme amacındadır. Onun görevi insanları düşünmekten uzaklaştırmak yerine, onlara felsefe yapmasını öğretmektir. Sinemanın bunu 
yapabilecek kapasitesi vardır (Bazin, 2011, s. 10). Bazı düşünürler felsefenin öldüğünü iddia etmiş olsalar bile aksine felsefe, sinemayla bir olup daha güçlü iddialarla düşün dünyasına katkı sunmaya devam etmektedir.

Sinemanın her yaştan insana ulaşma gayesi dünyanın her yerinde aynı strateji üzerinden devam etmektedir. Ama Amerika'nın dünyaya görsel alanda açılan kapısı ve sinema piyasasının en güçlü ismi olan Hollywood gençliğe ayrı bir yaklaşım sergilemektedir. Gençlerin neden Hollywood tarafindan hedef alındığına dair birçok tartışma devam etmektedir: bunun farklı nedenleri olmakla birlikte öncelikle gençlerin eğlence harcamalarını sevdikleri için harcanabilir gelirleri mevcut; ikincisi bugünün çocukları yarının tüketen ebeveynidir son olarak da sinemacıların kendi kayıp gençliklerini şimdiki nesilde deneyimleme isteği, yoğunluğun gençler üzerinde toplanmasına sebep olmaktadır (Shary, Generation Multiplex : The Image of Youth in Contemporary American Cinema, 2002, s. 2).

Bu noktada sinema ve dolayısıyla film üzerinden verilen mesajların özellikle hedef kitle olan gençler tarafindan bilinmesi gerekir. Bunu yapmanın yegâne gerçekleştiricisi ise sinema dilini ve sinema zihin dünyasını algılayabilmektir. Özön sinema ile ilgili başka bir eserinde sinema dilinin öneminden bahsetmektedir. Ona göre, sinema sanatının anlaşılması için, sinema dilinin bütün inceliklerinin öğrenilmesi gereklidir: Sinema görüntülerinin yanıltıcıllğı. Çünkü bu görüntüler bize gerçeği olduğu gibi yansıtabildiği denli, bizi yanıltmak, kandırmak, düşüncelerimizi yönlendirmek amacıyla da kullanılabilir. $\mathrm{Bu}$ görüntülerin yanıltma, kandırma, yönlendirme gücü, gerçekçi özelliğiyle doğru orantılıdır. Çünkü sinema izleyicisinin, sinema görüntülerinin gerçek olduğu yolunda bir önyargısı vardır. Bu önyarg1 sinemada gerçekçi türlere doğru ilerledikçe daha da ağırlık kazanır, filmlerde son kertesine varır (Özön, 2008, s. 17).

Janet Harbord, filmin, yaşam tarzı tüketimi için özel olarak konumlandırılmış ayrıcalıklı bir medya biçim araç olduğunu iddia etmektedir. Harbord'a göre, filmi video veya DVD olarak bir nesne olarak satın almak mümkün olsa da film izleme, bir nesneyi edinmekten ziyade deneyime dayanan bir kültürdür. Ancak ilişkili ürün ve sponsorluk ağına sıkıca gömülmüş olarak, bizi hayali bir medya aracıllğıyla bir dizi metaya yönlendirmektedir (Harbord, 2002, s. 89-90). Bu noktadan bakıldığında diğer düşünceler nezdinde de ele alındığında bütün sanatlar doğaları gereği ekonomik ürünlerdir ve bu nedenle ekonomik terimlerle değerlendirilmelidir. Yeniden, sinema ve diğer sanatlar, bu fenomenin başlıca örnekleridir. Mimarlık gibi, sinema ve kayıt sanatları da hem sermaye-yoğun hem de emek-yoğun sanatlardır; yani bunlar büyük paralar harcanmasını gerektirir ve çok sayıda çalışana gereksinim duyarlar (Monaco, 2000, s. 36). Ontolojik olarak, sinemanın özü, olağanüstü alemden ziyade aşkın deneyim yapılarına aittir, ancak sinema ile olan ilişkimizi karakterize eden bu yakınlık, bir filmin değiştirilebilir kopyalarını almamızı işaret eden ayrılma ile el ele gider (Phillips, 2008, s. 8).

\section{YÖNTEM}

\section{Örneklem}

Araştırmanın örneklemini, Bingöl Üniversitesi Fen-Edebiyat Fakültesi Sosyoloji bölümü 1.2.3. ve 4.sınıf öğrencilerinden, toplam 96 üniversite öğrencisi oluşturmaktadır.

Ankete katılan 96 öğrencinin cinsiyet dağılımına bakıldığında; öğrencilerin \%70,8 oranında kız, $\% 28,1$ oranında erkek öğrencilerden oluştuğu görülmektedir.

\section{Veri toplama aracı}

Araştırmacılar tarafından oluşturulmuş olan anketin ilk kısmında öğrencileri cinsiyetini belirlemeye yönelik soru bulunmaktadır. Sonraki kısımlarda ise daha çok öğrencilerin film tercihlerini belirlemeye yönelik gündelik yaşamdan yola çıkılarak sosyo-kültürel düzeylerini de ölçmenin hedeflendiği sorular yöneltilmiştir.

\section{Uygulama}

Anket uygulaması sınıflarda öğrencilerle toplu olarak gerçekleştirilmiştir.

\section{Kodlama}




\section{Analiz}

Analiz için Kodlanan veri üzerinden sorulara verilen tercihler için frekans tabloları çıkartılmıştır. Daha sonra tercihlere yazılan frekanslar toplanmış ve bunlar tablolaştırılmıştır. Ayrıca cinsiyete göre farklılaşmalar, tercihlerin toplamı üzerinden ki kare analizi ile yapılmıştır.

\section{BULGULAR}

\section{Film İzleme Sıklığı}

Üniversite öğrencilerin film izlemedeki zaman aralığına verilen cevaplara bakıldığında, seçeneklerden büyük bir çoğunluğunun "haftada bir" olduğu görülmektedir (Bkz. Tablo 1).

Tablo 1. Ne s1klıkla Film izlersiniz?

\begin{tabular}{|l|l|l|l|l|l|}
\hline & Frequency & Percent & $\begin{array}{l}\text { Valid } \\
\text { Percent }\end{array}$ & \multicolumn{2}{|c|}{ Cumulative Percent } \\
\hline Valid & Her gün & 7 & 7,3 & 7,4 & 7,4 \\
\cline { 2 - 6 } & Haftada bir & 43 & 44,8 & 45,7 & 53,2 \\
\hline & Ayda bir & 23 & 24,0 & 24,5 & 77,7 \\
\hline & Yılda bir & 4 & 4,2 & 4,3 & 81,9 \\
\hline & Diğer & 17 & 17,7 & 18,1 & 100,0 \\
\hline Missing & Total & 94 & 97,9 & 100,0 & \\
\hline Total & System & 2 & 2,1 & & \\
\hline
\end{tabular}

Ankete katılan öğrencilerin \%44.8'i haftada bir gün film izlediklerini belirtmişlerdir. Haftada bir gün film izleyenleri \%24 oranında ayda bir gün film izleyenler takip etmektedirler. Yılda bir gün film izleyenlerin oran 1 ise; $\% 4.2$ 'dir.

\section{Film Türü}

Öğrencilere genellikle izeldikleri film türleri sorulduğunda vermiş oldukları cevap seçeneklerinde frekans tablosunda \%26'lık bir oranla Aksiyon filmleri tercih edilirken ikinci siray1 \%22'lik oranla bilim-kurgu tarzı filmler tutmaktadır. Kümülativ yüzdelikte ise Bilim-kurgu tarzı filmler \%91'lik bir büyüklükle en yüksek orana sahip olduğu görülmektedir.

Tablo 2. Sevdiğiniz Film Türü

\begin{tabular}{|l|l|l|l|l|l|}
\hline & Frequency & Percent & $\begin{array}{l}\text { Valid } \\
\text { Percent }\end{array}$ & \multicolumn{2}{|c|}{ Cumulative Percent } \\
\hline \multirow{2}{*}{ Valid } & Aksiyon & 26 & 27,1 & 28,3 & 28,3 \\
\cline { 2 - 6 } & Gerilim & 7 & 7,3 & 7,6 & 35,9 \\
\hline & Korku & 6 & 6,3 & 6,5 & 42,4 \\
\hline
\end{tabular}




\begin{tabular}{|l|l|l|l|l|l|}
\hline & Komedi & 20 & 20,8 & 21,7 & 64,1 \\
\hline & Romantik & 3 & 3,1 & 3,3 & 67,4 \\
\hline & $\begin{array}{l}\text { Bilim- } \\
\text { kurgu }\end{array}$ & 22 & 22,9 & 23,9 & 91,3 \\
\hline & Diğer & 8 & 8,3 & 8,7 & 100,0 \\
\hline & Total & 92 & 95,8 & 100,0 & \\
\hline Missing & System & 4 & 4,2 & & \\
\hline Total & 96 & 100,0 & & & \\
\hline
\end{tabular}

İzlenilen film türü sorusunda \%27,1 oranı ile aksiyon filmi birinci sırada iken; romantik film ise \%3.1 oranı ile en az tercih edilen film türü olmuştur. Film tercihinde aksiyon filmlerinden sonra bilim-kurgu filmlerinin ağırlıklı olduğu (\%22.9) görülmektedir.

Ayrıca Ki Kare analizlerine bakıldığı zaman;

Tablo 3. Film türü ve Cinsiyet İlişki Tablosu

\begin{tabular}{|c|c|c|c|c|c|}
\hline & & & $\mathrm{k} 1 \mathrm{z}$ & erkek & \\
\hline \multicolumn{2}{|l|}{ Film türü } & \multicolumn{2}{|r|}{ Aksiyon } & Count & 13 \\
\hline filmtürü & Aksiyon & \% within filmtürü & $52,0 \%$ & 12 & 25 \\
\hline \multirow[t]{12}{*}{ Total } & Gerilim & $\%$ within cinsiyetiniz & $19,7 \%$ & $48,0 \%$ & $100,0 \%$ \\
\hline & & $\%$ of Total & $14,3 \%$ & $48,0 \%$ & $27,5 \%$ \\
\hline & & Count & 4 & $13,2 \%$ & $27,5 \%$ \\
\hline & \multirow{4}{*}{$\begin{array}{l}\text { Gerilim } \\
\text { Korku }\end{array}$} & $\%$ within filmtürü & $57,1 \%$ & 3 & 7 \\
\hline & & $\%$ within cinsiyetiniz & $6,1 \%$ & $42,9 \%$ & $100,0 \%$ \\
\hline & & $\%$ of Total & $4,4 \%$ & $12,0 \%$ & $7,7 \%$ \\
\hline & & Count & 6 & $3,3 \%$ & $7,7 \%$ \\
\hline & \multirow{4}{*}{$\begin{array}{l}\text { Korku } \\
\text { Komedi }\end{array}$} & \% within filmtürü & $100,0 \%$ & 0 & 6 \\
\hline & & $\%$ within cinsiyetiniz & $9,1 \%$ & $0,0 \%$ & $100,0 \%$ \\
\hline & & $\%$ of Total & $6,6 \%$ & $0,0 \%$ & $6,6 \%$ \\
\hline & & Count & 15 & $0,0 \%$ & $6,6 \%$ \\
\hline & Komedi & $\%$ within filmtürü & $75,0 \%$ & 5 & 20 \\
\hline
\end{tabular}




\begin{tabular}{|c|c|c|c|c|c|}
\hline & Romantik & $\%$ within cinsiyetiniz & $22,7 \%$ & $25,0 \%$ & $100,0 \%$ \\
\hline & & $\%$ of Total & $16,5 \%$ & $20,0 \%$ & $22,0 \%$ \\
\hline & & Count & 2 & $5,5 \%$ & $22,0 \%$ \\
\hline & Romantik & $\%$ within filmtürü & $66,7 \%$ & 1 & 3 \\
\hline & Bilim-kurgu & \%within cinsiyetiniz & $3,0 \%$ & $33,3 \%$ & $100,0 \%$ \\
\hline & & $\%$ of Total & $2,2 \%$ & $4,0 \%$ & $3,3 \%$ \\
\hline & & Count & 18 & $1,1 \%$ & $3,3 \%$ \\
\hline & Bilim-kurgu & $\%$ within filmtürü & $81,8 \%$ & 4 & 22 \\
\hline & Diğer & $\%$ within cinsiyetiniz & $27,3 \%$ & $18,2 \%$ & $100,0 \%$ \\
\hline & & $\%$ of Total & $19,8 \%$ & $16,0 \%$ & $24,2 \%$ \\
\hline & & Count & 8 & $4,4 \%$ & $24,2 \%$ \\
\hline & Diğer & $\%$ within filmtürü & $100,0 \%$ & 0 & 8 \\
\hline & Count & $\%$ within cinsiyetiniz & $12,1 \%$ & $0,0 \%$ & $100,0 \%$ \\
\hline & & $\%$ of Total & $8,8 \%$ & $0,0 \%$ & $8,8 \%$ \\
\hline & & 66 & 25 & $0,0 \%$ & $8,8 \%$ \\
\hline Total & & \% within filmtürü & $72,5 \%$ & $27,5 \%$ & 91 \\
\hline & & $\%$ within cinsiyetiniz & $100,0 \%$ & $100,0 \%$ & $100,0 \%$ \\
\hline & & $\%$ of Total & $72,5 \%$ & $27,5 \%$ & $100,0 \%$ \\
\hline
\end{tabular}

Kız öğrenciler \%27,3 oranında bilim-kurgu ağırlıklı filmleri tercih ederken; erkek öğrencilerin ise \%27,5 oranında aksiyon türü filleri tercih etmiş̦ir. Bilim-Kurgu temalı filmlerden sonra kız öğrencilerin film seçimlerinde sırasıyla komedi ve aksiyon tarzı filmler gelirken erkek öğrenciler de ise aksiyon filmlerinden sonra ikinci ve üçüncü sırayı Bilim-kurgu ve komedi filmleri taip etmektedir.

\section{Gündelik Yaşamda Film izleme Amacı}

Üniversite öğrencilerine film izlemedeki temel amaçlarının ne olduğu sorusu yöneltildiğinde verilen cevaplara göre öğrencilerin filmde başta heyecan, eğlenme ve gülme gibi duyguların ön plana çıktığı görülmektedir.

Tablo 4. Film izlemedeki amacinız?

\begin{tabular}{|l|l|l|l|l|l|}
\hline & Frequency & Percent & $\begin{array}{l}\text { Valid } \\
\text { Percent }\end{array}$ & \multicolumn{2}{|c|}{ Cumulative Percent } \\
\hline Valid & Eğlenmek & 25 & 26,0 & 26,9 & 26,9 \\
\hline
\end{tabular}




\begin{tabular}{|l|l|l|l|l|l|}
\hline & Heyecan & 34 & 35,4 & 36,6 & 63,4 \\
\hline & Gülmek & 12 & 12,5 & 12,9 & 76,3 \\
\hline & Duygusal & 4 & 4,2 & 4,3 & 80,6 \\
\hline & Teknoloji & 7 & 7,3 & 7,5 & 88,2 \\
\hline & Diğer & 11 & 11,5 & 11,8 & 100,0 \\
\hline Missing & Total & 93 & 96,9 & 100,0 & \\
\hline Total & System & 3 & 3,1 & & \\
\hline & 96 & 100,0 & & \multicolumn{2}{|l}{} \\
\hline
\end{tabular}

Tercih edilen filmlerin ne amaçla izlendiği sorusuna katılımcıların \%35.4'ü heyecan seçeneğini seçmişlerdir. $\mathrm{Bu}$ noktada öğrencilerin özellikle aksiyon yönünden imgelerle ifade edilebileceği söylenebilir. Duygusal seçeneğini seçenlerin oranı ise \%4.2'dir ve bu oran katılımcıların 4 tanesinin tercih edilen film türünün gündelik yaşamdaki katkısının duygusal amaçlı olduğunu göstermektedir.

\section{Film izlemede platform ve mekân tercihleri}

Film izleme platform ve mekân seçimlerinde gene öğrencilerin büyük bir bölümünün internet üzerinden film izlemeyi tercih ettiği sonucuna ulaşılmaktadır. Dolayısıyla internetin özellikle öğrencilerin filmlere erişim sağlamada büyük bir imkân sağladığı düşüncesine ulaşılabilir.

Tablo 5. Film izleme platform ve mekân seçimi

\begin{tabular}{|l|l|l|l|l|l|}
\hline & Frequency & Percent & $\begin{array}{l}\text { Valid } \\
\text { Percent }\end{array}$ & \multicolumn{2}{|c|}{ Cumulative Percent } \\
\hline \multirow{2}{*}{ Valid } & Sinemada & 3 & 3,1 & 3,2 & 3,2 \\
\cline { 2 - 6 } & $\begin{array}{l}\text { İnternet } \\
\text { Üzerinden }\end{array}$ & 33 & 34,4 & 35,1 & 38,3 \\
\hline & Evde & 24 & 25,0 & 25,5 & 63,8 \\
\hline & Hepsi & 31 & 32,3 & 33,0 & 96,8 \\
\hline & Diğer & 2 & 2,1 & 2,1 & 98,9 \\
\hline & 6,00 & 1 & 1,0 & 1,1 & 100,0 \\
\hline Missing & Total & 94 & 97,9 & 100,0 & \\
\hline Total & System & 2 & 2,1 & & \\
\hline
\end{tabular}

Ankete katılan kat1lımcıların \%34,4'ü filmleri internet üzerinden izlemeyi tercih ettiklerini belirtmişlerdir. İnternet üzerinden film izlemeyi tercih edenleri sinemada, evde ve diğer seçeneklerinin 
hepsini tercih edenler izlemektedir. Onların oranı ise; \%32,3'tür. Sinemada film izlemeyi tercih edenler ise katılımcılar arasında en düşük yüzdelik dilime sahip olanlardır. Oranları \%3’tür.

Ayrıca cinsiyet bağlamında verilen cevaplar analiz edildiğinde;

Tablo 6. Cinsiyet Bağlamında Film izleme platform ve mekân seçimi

\begin{tabular}{|c|c|c|c|c|c|}
\hline & & & \multicolumn{2}{|c|}{ cinsiyetiniz } & \multirow[b]{2}{*}{ Total } \\
\hline & & & $\mathrm{k} 1 \mathrm{z}$ & erkek & \\
\hline \multirow[t]{20}{*}{ Nerede izlersiniz } & Sinemada & Count & 3 & 0 & 3 \\
\hline & & $\%$ within neredeizlersiniz & $100,0 \%$ & $0,0 \%$ & $100,0 \%$ \\
\hline & & $\%$ within cinsiyetiniz & $4,5 \%$ & $0,0 \%$ & $3,2 \%$ \\
\hline & & $\%$ of Total & $3,2 \%$ & $0,0 \%$ & $3,2 \%$ \\
\hline & İnternet Üzerinden & Count & 25 & 8 & 33 \\
\hline & & $\%$ within neredeizlersiniz & $75,8 \%$ & $24,2 \%$ & $100,0 \%$ \\
\hline & & $\%$ within cinsiyetiniz & $37,3 \%$ & $30,8 \%$ & $35,5 \%$ \\
\hline & & $\%$ of Total & $26,9 \%$ & $8,6 \%$ & $35,5 \%$ \\
\hline & Evde & Count & 14 & 10 & 24 \\
\hline & & $\%$ within neredeizlersiniz & $58,3 \%$ & $41,7 \%$ & $100,0 \%$ \\
\hline & & $\%$ within cinsiyetiniz & $20,9 \%$ & $38,5 \%$ & $25,8 \%$ \\
\hline & & $\%$ of Total & $15,1 \%$ & $10,8 \%$ & $25,8 \%$ \\
\hline & Hepsi & Count & 24 & 6 & 30 \\
\hline & & $\%$ within neredeizlersiniz & $80,0 \%$ & $20,0 \%$ & $100,0 \%$ \\
\hline & & $\%$ within cinsiyetiniz & $35,8 \%$ & $23,1 \%$ & $32,3 \%$ \\
\hline & & $\%$ of Total & $25,8 \%$ & $6,5 \%$ & $32,3 \%$ \\
\hline & Diğer & Count & 1 & 1 & 2 \\
\hline & & $\%$ within neredeizlersiniz & $50,0 \%$ & $50,0 \%$ & $100,0 \%$ \\
\hline & & $\%$ within cinsiyetiniz & $1,5 \%$ & $3,8 \%$ & $2,2 \%$ \\
\hline & & $\%$ of Total & $1,1 \%$ & $1,1 \%$ & $2,2 \%$ \\
\hline
\end{tabular}




\begin{tabular}{|lllll|l|}
\hline Count & 0 & 1 & 1 \\
\hline \begin{tabular}{l} 
\% within neredeizlersiniz \\
\hline$\%$ within cinsiyetiniz
\end{tabular} & $0,0 \%$ & $100,0 \%$ & $100,0 \%$ \\
\hline \% of Total & $0,0 \%$ & $1,1 \%$ & $1,1 \%$ \\
\hline Tount & 67 & 26 & 93 \\
\hline \% within neredeizlersiniz & $72,0 \%$ & $28,0 \%$ & $100,0 \%$ \\
\hline$\%$ within cinsiyetiniz & $100,0 \%$ & $100,0 \%$ & $100,0 \%$ \\
\hline$\%$ of Total & $72,0 \%$ & $28,0 \%$ & $100,0 \%$ \\
\hline
\end{tabular}

Kı öğrencilerin \%37,3 gibi bir oranla filmleri internet üzerinden izlediği görülürken, erkek öğrencilerin $\% 38,5$ oranında evde film izlemeyi tercih ettiği görülmektedir. Bu büyüklüklerin dışında en yüksek oran olan hepsi seçeneğiyle spesifik bir alandan ziyade olanaklar dahilinde farklı mekân ve platformların da tercih edilebileceği sonucuna ulaşılmaktadır.

\section{Yeni filmlerden haberdar olma şekilleri}

Ulusal ya da uluslararası menşeili filmlerin vizyon tarihlerinin nerden ve nasıl öğrenildiğine dair soru yöneltildiğinde öürencilerin bir önceki anket sorusunda olduğu gibi sosyal medya ve dolayısıyla internet üzerinden bilgi erişimi sağlaması verilen cevapların parelellik gösterdiği sonucuna götürmektedir.

Tablo 7. Vizyona giren Filmlerden nasıl haberdar olursunuz?

\begin{tabular}{|l|l|l|l|l|l|}
\hline & Frequency & Percent & $\begin{array}{l}\text { Valid } \\
\text { Percent }\end{array}$ & \multicolumn{2}{|l|}{ Cumulative Percent } \\
\hline Valid & Gazeteden & 1 & 1,0 & 1,1 & 1,1 \\
\cline { 2 - 6 } & $\begin{array}{l}\text { Televizyon } \\
\text { Fragmanından }\end{array}$ & 7 & 7,3 & 7,4 & 8,5 \\
\hline \multirow{2}{*}{} & $\begin{array}{l}\text { Sosyal paylaşım } \\
\text { platformlarından }\end{array}$ & 86 & 89,6 & 91,5 & 100,0 \\
\hline Missing & Total & 94 & 97,9 & 100,0 & \\
\hline Total & System & 2 & 2,1 & & \\
\hline
\end{tabular}

Gösterime yeni giren filmlerden haberdar olma şekillerine bakıldığında katılımcıların büyük bir kısmının (\%89.6) sosyal paylaşım platformları sayesinde haberdar oldukları sonucuna ulaşılmıştır. Gazete vasıtasıyla filmlerden haberdar olma oranı ise \%1'dir. Bu noktadan bakıldığında elektronik veri akışı ve erişiminin diğer kategorilere göre daha yüksek oranda olduğunu göstermektedir. 


\section{Film İzlemede Gündelik Amaç Üzerine}

Öğrencilere film izlerken ne gibi kriterleri esas alırsınız şeklindeki sorulara verdikleri cevaplar göz önüne alındığında büyük çoğunluğun kültür seviyelerini artımada filmi bir araç olarak gördükleri gözlemlenmiştir.

Tablo 8. Film izlemedeki Gündelik amacınız?

\begin{tabular}{|l|l|l|l|l|l|}
\hline & Frequency & Percent & $\begin{array}{l}\text { Valid } \\
\text { Percent }\end{array}$ & \multicolumn{2}{|c|}{ Cumulative Percent } \\
\hline Valid & $\begin{array}{l}\text { Boş zamanı } \\
\text { değerlendirmek }\end{array}$ & 25 & 26,0 & 26,0 & 26,0 \\
\cline { 2 - 7 } & $\begin{array}{l}\text { Genel kültür } \\
\text { düzeyini } \\
\text { artırmak }\end{array}$ & 57 & 59,4 & 59,4 & 85,4 \\
\hline & Diğer & 14 & 14,6 & 14,6 & 100,0 \\
\cline { 2 - 7 } & Total & 96 & 100,0 & 100,0 & \\
\hline
\end{tabular}

$\mathrm{Bu}$ noktada Film izlemekteki temel amacının genel kültür düzeyini arttırmak olduğunu belirten katılımcıların oranı \%59.4'tür. Bu oranı \%26 ile boş zamanı değerlendirmek, \%14.6 ile diğer seçeneği takip etmektedir. Cinsiyet ve film izleme arasındaki ilişki aşağıdaki tablodan incelendiğinde;

Tablo 9. Gündelik amaç ve Cinsiyet İilişkisi

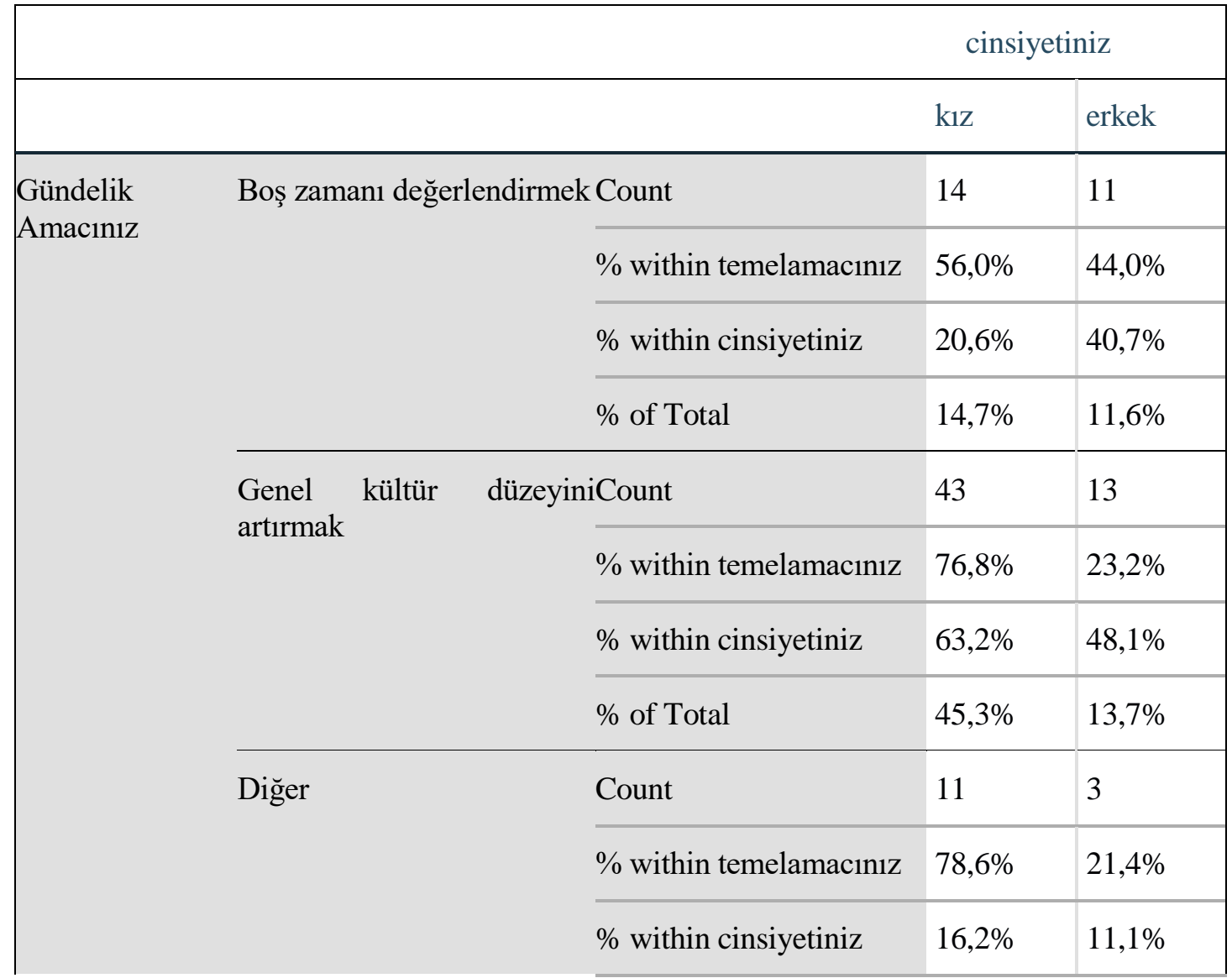




\begin{tabular}{|lll|l|}
\hline & \% of Total & $11,6 \%$ & $3,2 \%$ \\
\hline Total & 68 & 27 \\
\hline Count & 6 within temelamacinız & $71,6 \%$ & $28,4 \%$ \\
\hline \% within cinsiyetiniz & $100,0 \%$ & $100,0 \%$ \\
\hline \% of Total & $71,6 \%$ & $28,4 \%$ \\
\hline
\end{tabular}

Kız ve erkek öğrencilerin genel kültür seviyelerini yükseltmede film izlemeyi önemli bir unsur olarak kabul ettikleri görülmektedir.

\section{Kültürel Bir Faaliyet olarak Sinema}

Sinemaya gitmenin ve sinemada film izlemenin kültürel bir aktivite olup olmadığı sorusu yöneltildiğinde

Tablo 10. Sinemayı kültürel bir faaliyet olarak görme

\begin{tabular}{|c|c|c|c|c|c|}
\hline & Frequency & Percent & $\begin{array}{l}\text { Valid } \\
\text { Percent }\end{array}$ & \multicolumn{2}{|c|}{ Cumulative Percent } \\
\hline \multirow[t]{5}{*}{ Valid } & Katl1liyorum & 44 & 45,8 & 45,8 & 45,8 \\
\hline & $\begin{array}{l}\text { Kismen } \\
\text { Katılyyorum }\end{array}$ & 41 & 42,7 & 42,7 & 88,5 \\
\hline & Katılmiyorum & 5 & 5,2 & 5,2 & 93,8 \\
\hline & $\begin{array}{l}\text { Hiç } \\
\text { Katılmıyorum }\end{array}$ & 6 & 6,3 & 6,3 & 100,0 \\
\hline & Total & 96 & 100,0 & 100,0 & \\
\hline
\end{tabular}

Sinemaya gitmeyi kültürel bir faaliyet olarak görenlerin oranı; \%45.8'dir. Fakat bu fikre kısmen katılanlar ile \%42.7 katılanlar arasındaki farkın azlığı göze çarpmaktadır. Nitekim katılmıyorum (\%5.2) ile hiç katılmıyorum (\%6.3) seçeneğini seçenler arasındaki farkın azlığı da göze çarpmaktadır.

Bununla birlikte katılımcılara film izlemedeki kültürel bilincin ölçülmesine yönelik yukarıdaki soruyu biraz daha açarak farklı şekilde sorular da yöneltilmiştir. Özellikle seyrettikleri filmlerin kitaptan uyarlanıp uyarlanmamış olması, filmi yönetmeninden ya da oyuncularından dolayı izliyor olması gibi sorularla anlamlı bir ilişki kurulmasına yönelik birtakım bulgulara ulaşılmaya çalışılmıştır.

Tablo 11. Filmin yönetmeni için Sinemaya gitme tercihleri

\begin{tabular}{|c|c|c|c|c|c|}
\hline & Frequency & Percent & $\begin{array}{l}\text { Valid } \\
\text { Percent }\end{array}$ & \multicolumn{2}{|c|}{ Cumulative Percent } \\
\hline \multirow[t]{3}{*}{ Valid } & Katl1liyorum & 13 & 13,5 & 13,5 & 13,5 \\
\hline & $\begin{array}{l}\text { Kismen } \\
\text { Kat1liyorum }\end{array}$ & 40 & 41,7 & 41,7 & 55,2 \\
\hline & Katılmiyorum & 33 & 34,4 & 34,4 & 89,6 \\
\hline
\end{tabular}




\begin{tabular}{|l|l|r|r|r|r|}
\hline & $\begin{array}{l}\text { Hiç } \\
\text { Katılmıorum }\end{array}$ & 10 & 10,4 & 10,4 & 100,0 \\
\cline { 2 - 5 } & Total & 96 & 100,0 & 100,0 & \\
\hline
\end{tabular}

Film tercihinde filmi çeken yönetmenin etkisinin saptanılmaya çalışıldığı soruda kısmen katılıyorum ve katılmıyorum seçeneklerini işaretleyenlerin oranı arasında \%7.3'lük bir fark bulunmaktadır. Farka rağmen katılımcıların \%41.7'si film tercihlerinde yönetmenin etkisine kısmen katıldıklarını belirtmişlerdir.

Tablo 12. Filmin oyuncular için sinemaya gitme tercihleri

\begin{tabular}{|c|c|c|c|c|c|}
\hline & Frequency & Percent & $\begin{array}{l}\text { Valid } \\
\text { Percent }\end{array}$ & \multicolumn{2}{|c|}{ Cumulative Percent } \\
\hline \multirow[t]{5}{*}{ Valid } & Katl1liyorum & 36 & 37,5 & 37,5 & 37,5 \\
\hline & $\begin{array}{l}\text { Kismen } \\
\text { Kat1liyorum }\end{array}$ & 38 & 39,6 & 39,6 & 77,1 \\
\hline & Katılmiyorum & 17 & 17,7 & 17,7 & 94,8 \\
\hline & $\begin{array}{l}\text { Hiç } \\
\text { Katılmıyorum }\end{array}$ & 5 & 5,2 & 5,2 & 100,0 \\
\hline & Total & 96 & 100,0 & 100,0 & \\
\hline
\end{tabular}

Film seçiminde oyuncuların etkisinin saptandığı soruda ise; katılımcıların \%39,6'sı kısmen katıldıklarını belirtmişlerdir. Tamamıyla katılmadıklarını belirtenlerin oranı ise $\% 5,2$ 'dir.

Tablo 13. Kitaptan uyarlanan filmlerin izlenme tercihleri

\begin{tabular}{|c|c|c|c|c|c|}
\hline & Frequency & Percent & $\begin{array}{l}\text { Valid } \\
\text { Percent }\end{array}$ & \multicolumn{2}{|c|}{ Cumulative Percent } \\
\hline \multirow[t]{5}{*}{ Valid } & Katliliyorum & 38 & 39,6 & 39,6 & 39,6 \\
\hline & $\begin{array}{l}\text { Kismen } \\
\text { Kat1liyorum }\end{array}$ & 43 & 44,8 & 44,8 & 84,4 \\
\hline & Kat1lmiyorum & 11 & 11,5 & 11,5 & 95,8 \\
\hline & $\begin{array}{l}\text { Hiç } \\
\text { Katılmıyorum }\end{array}$ & 4 & 4,2 & 4,2 & 100,0 \\
\hline & Total & 96 & 100,0 & 100,0 & \\
\hline
\end{tabular}

Kitaptan uyarlanan filmlerin film tercihinde etkisinin ölçüldüğü soruda ise; katılımcıların \%44.8'i kısmen katıldıklarını belirtmişlerdir. Katılan, katılmayan ve hiç katılmayanların oranı ise toplamda \%55.3'tür.

Yukarıdaki tablolar incelendiğinde üniversite öğrencilerinin büyük bir çoğunluğunda filmin yanı sıra filmde emeği geçen yönetmenin ve oyuncularının etkisini büyük olduğu görülmektedir. Ayrıca kitaptan uyarlanan filmlerin tercih edilmesinin de azımsanmayacak oranda büyük olduğu gözlemlenmektedir. 


\section{DEĞERLENDİRME}

Genel anlamda Bingöl Üniversitesi'nde okuyan öğrencilerin film izleme ve sinemaya gitme alışkanlıklarının Türkiye'nin batı bölgelerinde yer alan üniversite öğrencileriyle ortalama aynı sıklıkta olduğu gözlemlenmiştir. Araştırmada dikkat çeken hususlardan bazıları şöyledir:

(1) Öğrencilerin haftada en az bir defa dahi olsa film izledikleri gözlemlenmiştir.

(1) Film türü tercihlerinde kız öğrencilerin erkek öğrenciler kadar aksiyon türü filmleri izledikleri görülmektedir.

(1) Öğrencilerin izledikleri filmlerde genel kültür düzeylerini artırmaya yönelik meyilleri de film izlemedeki tercihlerini belirleyen başka bir sebep olarak görülmektedir.

(1) Dolayısıyla film izlemeyi kültürel bir faaliyet olarak gören öğrencilerin sayısındaki oranın da aynı paralellikte takip ettiği görülmektedir.

Ayrıca genel anlamda üniversite öğrencilerinin film izlemede tercihlerini etkileyen faktörler çalışmasının son bölümünde yer alan 'sinemaya oyuncusu ve yönetmeni için giderim' ifadelerinin bulunduğu kısma baktığımızda Bingöl Üniversitesi’nde okuyan öğrencilerin yanıtları şöyle olmuştur;

- Sinemaya filmin yönetmeni için giderim ifadesine verilen cevap kısmen katıllyorum şeklinde olup oran 1 ise $\% 41,7$ civarındadır.

- $\square$ Öte yandan sinemaya filmin oyuncuları için giderim ifadesine verilen cevap kısmen katılıyorum şeklinde olup oranı ise \%39,6 civarındadır.

\section{SONUÇ}

Modern toplumlarda ilerlemenin bazı ölçütleri her dönem kendini hissettirmektedir. $\mathrm{Bu}$ ilerleme sürecinde özellikle gözler eski dönemlerde olduğu gibi günümüzde de gençler üzerindedir. Gençliğin kendi potansiyeli etrafında gelişim göstermesi nihai hedefe ulaşmada çoğu zaman yeterli olmayabilir. Dolayısıyla özellikle entelektüel anlamda farklı konseptlerle desteklenmeye ihtiyaç duyarlar. İşte bu noktada başta bilimsel aktiviteler olmak üzere sanatsal ve kültürel aktiviteler lojistik bir misyon üstlenmektedir.

Gençlik kategorizasyonunda en çok dikkati çeken, sadece Batı ülkelerinde değil Doğu ülkelerinde de büyük umutlarla beklenen grup, üniversite gençliğidir. Zira ilerleme yolunda yaşlı jenerasyondan bayrağı devralıp rakipleri ile yarışacak ve toplumlarını ileriye taşıyacak sınıf gene bahsetmiş olduğumuz üniversite gençliği olacaktır.

Dolayısıyla bu grubun maddi ve manevi potansiyelini takip etmek, desteklemek ve daha ileriye taşımak için yapılacaklar listesine ihtiyaç duyulmaktadır. Batı toplumları dijital çağ ile birlikte gelen tehlikenin farkında olduğundan gençler üzerinde farklı projeler ve stratejiler başlatalı bir hayli zaman olmuştur. $\mathrm{Bu}$ noktada ülkemizin de arasında yer aldığı doğu toplumlarında ise teknolojik ve kültürel anlamda yeteri kadar düşünce üretilememektedir. Düşünceden bağımsız kuru akılla düşünmeye çalışan gençlerin de geleceğe yönelik fikir ve kültür üretmemesi doğu toplumları adına büyük bir kayıp niteliğindedir. Modern zamanlarda insan biyografisi bir proje haline gelmiş ve yetişkin gençlerin ve ergenlerin statüsü değişmiştir. Gençler, bizim düşündügümüz gibi bazı kriterler eşliğinde otomatik bir şekilde büyümezler bunun yerine bazı önemli kavram kazanımlarında yetişkin kimliklerini elde ederler. Ergenler ve genç yetişkinler yaşam konseptlerini geliştirir, gündelik yaşamlarının içeriğini ve karmaşıklığını yönlendirmeye çalışırlar: aynı zamanda, çevrelerinin sürekli değişen taleplerine (özellikle işgücü piyasasına) uyum sağlamak zorunda kalırlar (Bois-Reymond, 2012, s. 63).

Kendilerine büyük umutların bağlandığı üniversite gençliğinde sanatsal anlamda ne gibi farkındalıkların mevcut olduğu konusunda yeteri kadar araştırmanın yapılmıyor olması kültürel anlamda ortak bir bilincin oluşmamasına da neden olmaktadır. Zira kültürel faaliyetlerin yoğun bir şekilde icra edilmesinin yegâne şartı bu şuura sahip olmaktan geçmektedir.

Verilerle destekleyip ifade etmeye çalıştığımız bu çalışmayla, Bingöl Üniversitesi öğrencilerinin film algısını, film izleme aktivitelerinin salt bir izlemeden mi ibaret olduğunu, entelektüel alt yapılarındaki 
birikimi kısmen de olsa açığa çıkarmaya ve bilimsel anlamda yazı diline aktarmaya çalıştık.

\section{KAYNAKÇA}

Bazin, A. (2011). Sinema nedir? (çev. İbrahim Şener). İstanbul: Doruk Yayımcılık.

Bois-Reymond, M. D. (2012). 'I don't want to commit myself yet': young people's life concepts. Journal of Youth Studies, 1(1), 63-79.

Harbord, J. (2002). Film cultures. London: Sage publications.

Monaco, J. (2000). Bir film nasıl okunur? (çev. E. Yı1maz.) İstanbul: Oğlak Yayıncılık.

Phillips, J. (2008). Cinematic thinking philosophical approaches to the new cinema. Stanford: Stanford University Press.

Shary, T. (2002). Generation multiplex : the image of youth in contemporary American cinema. Austin, Amerika Birleşik Devletleri: Texas Press.

Shary, T., \& Seibel, A. (2007). Youth culture in global cinema. Austin, Amerika Birleşik Devletleri: Texas Press.

Özön, N. (1984). 100 soruda sinema sanatı. İstanbul: Gerçek Yayınevi.

Özön, N. (2008). Sinema sanatına giriş. İstanbul: Agora Kitaplığı.

Özarslan, E. (2015). Sinema kuramlarl-1 beyaz perdeyi aydınlatan kuramcılar. İstanbul: Su Yayınları. 